\title{
Applying a Journal Project to Learners and Learning
}

\author{
Yuna Kadarisman
}

DOI: 10.17977/um013v1i22017p91

MAN Insan Cendekia Serpong, Indonesia

\section{History Article}

Received 18 April 2017

Approved 28 May 2017

Published 7 June 2017

\section{Keywords}

journaling, writing,

learning

\begin{abstract}
This paper explores learners and learning based on my case study. I will discuss learner characteristics based on my prediction of how learning would happen when I developed the project. Then I will discuss motivation and interests impacting on learners where I will further explore how learning actually happened. The following discussion will concern the context of the learning environment where I analyse factors that impact on learning and learners. Then, I will also explore my reflections on the learning process and introduce my plans to improve my teaching strategies in the future. Throughout the discussion I will refer to two different types of results, based on the general result of teaching and learning activity and based on Ikbar's case, which showed a deviation from general performance.
\end{abstract}

\section{How to Cite}

Kadarisman, Y. (2017). Applying a Journal Project to Learners and Learning. Classroom Action Research Journal, 1(2), 91-98. 


\section{INTRODUCTION}

I noticed that the biggest problem for my Year 10 English students was writing. Some students said they were afraid of making grammatical mistakes. Some said they had difficulty in finding ideas to write about. Others blamed their limited vocabulary. Then, I initiated a journal project. The objective was to encourage students to write. Students were expected to articulate their ideas and arguments in writing. The students had to write at least seven journal entries. Each entry was worth 10 points. So, if they wanted to reach 100 points, they simply had to write 10 entries. In each English class, the students submitted one journal entry. I would then give feedback on the content and one grammar correction. Students could write about anything in their journal. However, many of my students still had difficulties in writing an entry as they found the freedom of subject overwhelming. Thus, sometimes I asked some questions in my feedback to give them ideas about what to write in the next entry. Each student was given a folder where they could keep their writings. I told my students that I would give them points based on the available journals. I also used the folder to observe the progress of my students' language abilities.

At times, I was very happy with the progress of my students. Many gained confidence to write longer stories. Others developed reflective essays where they commented on their life in the dormitory. However, one student, Ikbar, wrote something totally different. His last entry showed a sudden increase in language usage. This entry had very few grammar mistakes and used sophisticated vocabulary. Later I found that the entire entry was taken from a Wikipedia entry. Then, I called Ikbar outside of the classroom. He admitted nothing, nor did he defend himself in the case. As a consequence, I cancelled his previous five entries and he had to start from scratch next meeting.

In the next journal entry, he wrote me two pages of angry notes. He told me that he felt that I had treated him badly and his consequence was too harsh for a simple mistake. It was the longest entry he had ever written in the project. Yet it was the best entry I could expect a student to write. The writing was very argumentative and well developed. There were some grammar mistakes but they did not affect the content of the writing. I praised the journal entry highly. I could see his satisfaction once he read my feedback. However, he never put the entry into the folder. His next journals were about many different topics unlike his previous five entries that usually described his daily activities. He did not finish ten journals and only wrote seven as the minimum required. However, I told him I still granted him 100 points as he had shown great progress in the project.

\section{METHOD}

The research approach used is qualitative descriptive analytic research. The data obtained from the study are clearly described and analyzed to find the relationship then issued with a form of words in order to obtain information, and then presented in the form of a narrative description. This type of research is case study. This research used instruments such as observation based on the general result of teaching and learning activity and based on Ikbar's case, which showed a deviation from general performance. 


\section{RESULT AND DISCUSSION Learners characteristics}

My class was a year 10 who were generally $15-16$ years old. Based on Piaget's theory of cognitive development, such students are in the formal operational stage (Marsh, Clarke, \& Pittaway, 2015). They can imagine ideal scenarios for certain circumstances. They are often involved in egocentric activities such as analysing their own beliefs and attitudes. Moreover, my students could have been classified into five major personality types as described by Komarraju, Karau, Schmeck, \& Avdic (2011). Most of them were conscientious and agreeable. These students were able to collect the journal in time and finish the entire project on time. Some of them were extroverts. They mostly found words inadequate to express what they meant. Thus, they usually drew pictures or diagrams to ensure that the reader would follow their ideas. Some of them displayed the characteristic of openness. These students mostly came with new ideas, new topics to discuss. Some students were neurotic; they had some degree of emotional instability, impulse control, and anxiety. I found Ikbar in this personality category as he showed different changes throughout the project. $\mathrm{He}$ was not very conscientious as he missed some deadlines even though he was still working at a tolerable pace. However, after the incident, he showed progress in writing and was catching up as he had to write more journals to meet the target. I realised that these different personalities would result in different learning styles (Komarraju, Karau, Schmeck, \& Avdic, 2011), which would require me to develop different approaches in order to optimise their learning experiences.

Even though many studies could not find the relation between learning styles and students' academic performance (Cuevas, 2015; Komarraju, Karau, Schmeck, \& Avdic, 2011; Vinalesand, 2015; Wong \& Nunan, 2011), it is important for me to learn about my students' learning styles and preferences to develop more engaging learning instructions. I found that Kold inventories (Cuevas, 2015) were inadequate to describe my students' learning styles and preferences as in language learning there are more than just visual, auditory, reading-writing, and kinesthetic (VARK) approaches. I would rather use the learning styles introduced by K. Willing (Wong \& Nunan, 2011) that divides learner strategy preferences into communicative, analytical, authority-oriented and concrete. I assumed that my journalling project could give equal opportunities to these four different learning preferences. For communicative students, they could develop the journal in a communicative form as if they were talking to an audience. My analytical students could also benefit from this journalling as I provided feedback on their grammar competence. In fact, I did have several students who asked me to provide more thorough grammar feedback as they said they learnt more from my feedback on their writings. My authority-oriented students could also use this project to express their knowledge in a different format. In fact, I had students who wrote down what they had learnt in other subjects into their journals and admitted that that way they would learn English and the other subjects better. Then, my concrete students would find the journalling as a game because I set a target to achieve and provided extra points for those who wrote more than 10 journal entries. In general, I found that this project of writing a journal provided opportunities for students with different personalities and learning preferences to reach their optimal abilities in English. 
This is in line with the research of Komarraju, Karau, Schmeck, and Avdic (2011) who presume that teaching techniques serve more as mediator between personality and academic achievement rather than enhancing academic attainments. Wong and Nunan (2011) support my perspective as they claim that learners who are taught in accordance with their learning strategies and preferences are more motivated and learn more effectively.

\section{Motivation and interests impacting on the learners}

All of my students were adolescents and lived in a dormitory away from their family. They had limited access to contact their parents. Their parents could only see them once every fortnight on Sundays. McInerney (2015b) suggests that adolescence is a time when a great personal change occurs. Adolescents, then, would find parents, teachers and friends as role models during this personality development stage. However, instead of having their family to help nurture their growing characters, my students found in their place their friends at the dormitory and their teachers at school. Aside from personality, they also underwent a motivational change. My school is a selective school that only accepts 120 students from around 3000 applicants each year. All of my students are the most talented and the smartest of the applicants. However, when they start living in the dormitory, they meet other talented and gifted students. This affects their motivation in learning as they start comparing themselves with others. Most students have a great sense of self before they start learning at the school. However, as they start learning about others' great achievements in the past, many of them then feel inadequate and less smart. Thus, when I conducted early-need assessment analysis before implementing the project, some students said they were grammatically incompetent, some said they had less or no ideas to write about and others said they had limited vocabulary with which to start writing. However, this low self-concept was not reflected in their initial work. I could see their potential and aimed to help them see that too. Then I initiated the journal project as it could support their learning process and to enter the students' world as individuals (Castellanos, 2008).

In the early stages of the project, most of my students would only describe their daily activities. They thought that such a topic would be the most appropriate one to discuss in journal writing. I could also see that most of my students expected me to give feedback on their grammatical performance as this would be what they believed students at selective schools would get - a constant cognitive performance check. Thus, many of them were surprised when I only gave one item of grammar feedback and more content-related feedback. After I led them into a deeper discussion to learn more of their personal opinion through my feedback, many of my students started to explore more ideas. However, I could see that many saw me as part of the school system which sometimes did not meet their aspirations. They felt reluctant to express their personal view as opposed to describing their friend's view. Thus, I had to take an oath of discretion to never share the content of their writing with anyone unless there was a life-and-death case involved. Afterwards, I could see that I gained their trust as I read more personal views and personal arguments growing in their writing. This also showed how they developed their writing and how they increased their new self-concept in English and writing. Thus, by the end of the project, I could see that most of my students found writing in English just another way to communicate. It is more 
about what they want to say than what grammar errors they make. This concurs with Marrow (in Tunks, 2011) who suggests that journalling improves fluency, provides practice with the mechanics of writing, and helps students choose topics and reflect on ideas.

As I found that the journal project positively affected my students' selfesteem, optimism, motivation, and wellbeing, there was Ikbar, who struggled between matching his friends' development and his own expectations of achievement. Then, as he focused more on attaining a good grade than developing his own skills at his own pace (Tsai, 2012), he cheated by copying an entry from Wikipedia. Ikbar had an interpersonal intelligence as he was selected to be the student president later in the year. He had little or almost no problem in communication. However, as his self-concept saw English as a subject rather than a communication skill, he aimed at getting good marks rather than focusing on writing his own ideas. After I talked about his unacceptable behaviour, he started to see the objective of the project to use English to communicate and express ideas rather than to achieve perfection and grammar competency.

\section{Context of the learning environment}

In our school, we demand that the students show excellent cognitive attainment. Students who do not show constant required achievement have to leave the school. In light of this high-stake demand of schooling, I can understand that most of my students focus on cognitive attainment rather than a balanced show of cognitive, affective and psychomotor skills. When I explained that the journal project would not score their grammar attainment but rather their completing an entry, most of my students saw this as an easy way to gain cognitive points. As a result, they responded to my content-related feedback but neglected my grammar feedback and kept making similar grammar mistakes throughout the project.

\section{Reflection on Learning}

Prior to the project, students were made aware of the objectives and the underlying strategies of the project so they could work as expected. Wong and Nunan (2011) point out that learners who understand the underlying strategies of their learning are more motivated and develop the best strategies to fit their learning preferences.

I made the journalling the homework so students could prepare it before they came into the class. According to Fisher, Lapp and Frey (2011), there are four categories of students in relation to how they approach homework. Most of my students were completers who could get the journal done totally as expected. I also had some bewildered students who tried to do it but did it not as expected. For these students, I gave more feedback on their paper to explain what they had been missing or how I expected them to perform in their next journal. I found some slackers who did not complete the homework within the expected time. I made this journalling project a ticket to attend the English exam week. They well knew that if they did not make it to the exam week, they would have to deal with the principal and suffer the possibility of being expelled for not completing a subject. I did not tell the students these far-end consequences as I did not want them to feel threatened. However, for these slackers, I wrote extra notes to remind 
them of the time limit and how I treated completing this project as a ticket to join an exam week. In the end, I had 100\% completion. Fisher, Lapp and Frey (2011) include one last category - cheaters - which I find degrading. I understand that Ikbar would fit into this category as he copied his work from another source in an effort to please the demand and not fall behind in class. However, I appreciate his effort to copy the whole entry into his journal. I believe it would be easier and less time consuming for him to write about his daily activities like his writings before, yet he searched for a different entry to impress me. I agree that he was wrong for copying another's work but I appreciated his extra effort to try to meet the project expectations.

\section{Implication on Future Learning}

At the end of the project, I had $91 \%$ students completing the project up to the bonus stage where they wrote more than 10 journal entries and got 110/100 points. Moreover, I had 11 students (9\%) work until they got 100 points. Ikbar managed to write up to seven journal entries, which was the minimum requirement to pass the project; however, I gave him 30 extra points as he had shown great progress after the Wikipedia incident. Even though cognitively the project was a success, I feel that somehow I was neglecting the affective aspect of learning. Thus, I developed some suggestions to improve the project in future regarding the affective and cognitive development of my students.

Being honest and responsible are two affective attainments that Indonesian students are expected to develop and reach (MEC, 2014). Strom and Strom (2007) suggest that to avoid students cheating on an assignment, teachers should make the assignment purposeful, relevant, encourage personal views, and emphasise higher-order thinking. For the next journal project, in order to be purposeful, I need to work together with the students to set the rules and consequences of the project. Fisher, Lapp and Frey (2011) suggest that if students feel that they are in control of their learning, they will feel more responsibility to their own success in learning. Thus, by working on the rules, merit and consequences together I hope to invite more engagement from the students and less cases of cheating.

Roper (2014) suggests that teachers should also consider affective attainments in their lesson planning. Thus, students would not only develop in terms of knowledge but also in terms of attitude and awareness. As a teacher, it is one of my jobs to develop a lesson plan that encourages affective attainment. Through journalling, I could also help develop a persistent and disciplined attitude in my students. In my study case, I had not appreciated students who handed in their journal on time so they finished the project some weeks before the rest of the class. They were being persistent in their progress and disciplined in their time. I failed to recognise that. However, I do not want students to value the journal as a means to gain scores. I want my students to see journalling as their way of developing their communication skills. Thus, instead of rewarding them with a bonus score, I am thinking of rewarding them with a homework pass, with which they get extra time by not doing homework. I sometimes give homework to broaden and deepen students' understanding (Fisher, Lapp, \& Frey, 2011), and these students have shown their skill in writing, so missing a homework on writing would not harm their skill. In fact, they would feel appreciated as they would have shown their achievements in writing, and I would feel helped by having fewer papers to check. 
In my study case, students were allowed to use pictures and graphs to develop their journal. They showed some form of creativity in approaching the project. However, I did not recognise this. In the next project, I could consider this form of creativity as part of the assessment. I am thinking of developing a Journal Wall of Fame bundle where I will place the best journal entries my students have ever written. However, I also understand I should get my students' permission to put their entry in the bundle as some of them are private and would need adjustments before we allow public access. This form of recognition could help increase students' self-concept and motivation. Thus, my students would become effective learners who learn based on their own preference. Later, they would gain autonomy in learning and perceive language as a tool of communication rather than a subject to be studied as other school subjects. Thus, they would actively use language and seek to practise it in a naturalistic situation (Wong \& Nunan, 2011).

\section{CONCLUSION}

My study case has discussed a journalling project. Cognitively, this project was aimed to develop my students' writing skills. Moreover, this project was also aimed at helping develop my students' argumentative skills. Thus, even though in the early stages, many of my students described their daily life in their journal, through the feedback, they responded by writing more critically and showing more arguments. Another cognitive recognition was through extra points that were given to students who wrote more entries. Students were given 10 points for every entry they submitted. However, in the end 109 students (91\%) reached 110 points and the rest got 100 points. Despite this cognitive success, I somehow neglected the affective development. There was the case of Ikbar. Ikbar focused more on academic attainment and neglected academic honesty. This could happen as he felt pressured to catch up with his friends' progress (Khodaie, Moghadamzadehb, \& Salehia, 2011). Moreover, this act could also reflect the underlying processes of self-regulation: inhibitory control, impulsivity and affective distress (Callender, Olson, Kerr, \& Sameroff, 2010). Ikbar was highly motivated but had performance goal orientations rather than mastery goal orientations (Brown-Wright, et al., 2013). Thus, for the next project, I should develop one that helps students build their cognitive and affective skills properly.

\section{REFERENCES}

Brown-Wright, L., Tyler, K. M., Stevens-Watkins, D., Thomas, D., Mulder, S., Hughes, T., Smith, L. T. (2013). Investigating the Link between HomeSchool Dissonance and Academic Cheating among High School Students. Urban Education, 48(2), 314-334.

Callender, K. A., Olson, S. L., Kerr, D. C., \& Sameroff, A. J. (2010). Assessment of Cheating Behavior in Young School-Age Children: Distinguishing Normative Behaviors From Risk Markers of Externalizing Psychopathology. Journal of Clinical Child \& Adolescent Psychology, 39(6), 776-788.

Castellanos, J. (2008). Journal Writing and its Benefits in an Upper Intermediate EFL Class. Profile: Issues in Teachers' Professional Development, 9(1), 111-128. 
Cuevas, J. (2015). Is Learning Styles-based Instruction Effective? A Comprehensive Analysis of Recent Research on Learning Styles. Theory and Research in Education, 13(3), 308-333.

Fisher, D., Lapp, D., \& Frey, N. (2011). Homework in Secondary Classrooms: Making It Relevant and Respectful. Journal of Adolescent \& Adult Literacy, 55(1), 71-74.

Khodaie, E., Moghadamzadehb, A., \& Salehia, K. (2011). Factors Affecting the Probability of Academic Cheating School Students in Tehran. ProcediaSocial and Behavioral Sciences, 29, 1587-1595.

Komarraju, M., Karau, S. J., Schmeck, R. R., \& Avdic, A. (2011). The Big Five Personality Traits, Learning Styles, and Academic Achievement. Personality and Individual Differences, 51, 472-477.

Marsh, C. J., Clarke, M., \& Pittaway, S. (2015). How Students Develop and Learn. In Understanding Learning (Ed. Monash University, pp. 31-54). Sydney, Australia: Pearson Australia.

McInerney, D. (2015b). Social, Emotional, and Moral Development. In Understanding Learning (Ed. Monash University, pp. 252-296). Sydney: Pearson Australia.

Minister of Education and Culture (MEC). (2014). Peraturan Menteri Pendidikan dan Kebudayaan [Minister of Education and Culture Regulation] no. 59/2014. Kurikulum 2013 untuk Sekolah Menengah Atas/Madrasah Aliyah.

Roper, L. (2014). Respecting and Supporting Students' Affective Learning. Journal of College and Character, 15(1), 51-54.

Strom, P. S., \& Strom, R. D. (2007). Cheating in Middle School and High School. Educational Forum, 71(2), 104-116.

Tsai, C.-L. (2012). Peer Effects on Academic Cheating among High School Students in Taiwan. Asia Pacific Education Review, 13(1), 147-155.

Tunks, K. (2011). Exploring Journals as a Genre for Making Reading-Writing Connections. Childhood Education, 87(3), 169-176.

Vinalesand, J. J. (2015). The Learning Environment and Learning Styles: A Guide for Mentors. British Journal of Nursing, 24(8), 454-457.

Wong, L. L., \& Nunan, D. (2011). The Learning Styles and Strategies of Effective Language Learners. System: An International Journal of Educational Technology and Applied Linguistics, 39(2), 144-163. 